\title{
Energy, protein, zinc and copper status of twenty-one elderly inpatients: analysed dietary intake and biochemical indices
}

\author{
By ANITA J. THOMAS ${ }^{1,2}$, VALDA W. BUNKER ${ }^{2}$, LESLIE J. HINKS ${ }^{2}$, \\ NIDISH SODHA ${ }^{2}$, MARK A. MULLEE ${ }^{3}$ AND BARBARA E. CLAYTON ${ }^{2}$ \\ ${ }^{1}$ Geriatric Medicine, ${ }^{2}$ Chemical Pathology and Human Metabolism, and ${ }^{3}$ Medical \\ Statistics and Computing, Medical Faculty of the University of Southampton, Level D, \\ South Laboratory Block, Southampton General Hospital, Tremona Road \\ Southampton SO9 $4 X Y$
}

(Received 1 September 1987 - Accepted 11 November 1987)

1. Duplicate diet analysis for energy, protein, zinc and copper with estimates of biochemical status for $\mathrm{Zn}$ and $\mathrm{Cu}$ were undertaken in twenty-one elderly long-stay inpatients (mean age 82 (range 63-89) years) consuming their customary hospital diet and in a stable medical condition. Fourteen patients had a long-standing and significant healing problem, either a leg ulcer or pressure sore.

2. Mean daily intakes of energy $(5 \cdot 2 \mathrm{MJ})$, protein $(45 \mathrm{~g}), \mathrm{Zn}(85 \mu \mathrm{mol})$ and $\mathrm{Cu}(14 \mu \mathrm{mol})$ were low in comparison with both official recommendations and levels of intake at which metabolic equilibrium was observed in healthy elderly people studied by the same methods (Bunker et al. 1984a).

3. Mean leucocyte $\mathrm{Zn}\left(9 \mathrm{pmol} / 10^{6}\right.$ cells) and $\mathrm{Cu}\left(7 \cdot 5 \mathrm{pmol} / 10^{6}\right.$ cells $)$ were low in comparison with results from healthy elderly people (Bunker et al. 1984a), implying suboptimal status for these elements. Those patients with healing problems tended to have the lower values within the range.

4. Recommendations are made with respect to improving nutritional status in this disadvantaged group of people.

Experts doubt the capacity of the Health Service to meet the ever increasing demands of an ageing population, many of whom are chronically ill and disabled (Grundy, 1984; Andrews, 1985). In 1984 over one-third of all general medical and surgical beds were occupied by patients over 65 years of age (Department of Health and Social Security (DHSS), 1986). The elderly are at risk of poor nutrition for a number of reasons including economic pressures, poor dentition, reduced mobility, depression, loneliness and ageing tissues. Adequate intake of elements required in trace amounts may be particularly threatened. Clinical signs of frank nutritional deficiency are unusual, but fractured bones, pressure sores and leg ulcers are common and produce healing problems which are costly in both human and economic terms. The number of hospital admissions for fractured neck of femur alone (classically a disease of elderly women) has more than doubled in the last 20 years (Fenton Lewis, 1981). Elements other than calcium and phosphorus may be important in the pathogenesis of osteoporosis, as suggested by the finding that higher levels of intake in women are related to lower rates of loss of bone-mineral content as measured by single photon absorptiometry (Freudenheim et al. 1986). Zinc and copper have an important role in both healing and immunity, and $\mathrm{Cu}$ is vital to the integrity of connective tissues (Chandra, 1980; Solomons, 1985). There is no specific recommendation for the intake of trace elements in the elderly, either in the UK or the USA, and the only guidelines available are derived from studies of younger individuals (DHSS, 1979 $a$; Food and Nutrition Board, 1980).

Our previous work on the trace-element content of hospital meals revealed an intake of $\mathrm{Zn}$ and $\mathrm{Cu}$ approximately half that recommended for younger individuals even if elderly patients were assumed to eat everything selected by them or on their behalf (Thomas $e t$ al. 1986). The present study reports findings of actual dietary intake by analysis from duplicate meals and uneaten food over a $5 \mathrm{~d}$ period for a group of elderly inpatients. 


\section{EXPERIMEN T AL}

\section{Subjects}

Twenty-one inpatients of a geriatric unit devoted to the care of patients whose rehabilitation is expected to take longer than 3 months (slow-stream rehabilitation) and those whose discharge from hospital is unlikely (long stay) (Hall, 1974) took part. They included seventeen women and four men with an overall mean age of 81.7 years (range 63-89 years). Fourteen patients had a long-standing ( $>6$ months) and significant healing problem, either a pressure sore or leg ulcer. None of them smoked. Eighteen were edentulous, and eleven reported problems with ill-fitting dentures. The patients had been resident on the ward and had consumed hospital food for more than 3 months. They were weighed weekly as part of normal ward routine, on the same scales. Patients were not included if they had gastrointestinal, hepatic, or renal disease or had been receiving vitamin and mineral supplements. None of them were taking prostaglandin-synthetase inhibitors or chelating agents and note was taken of all other medication including thiazide diuretics. The 'intervention effect' was minimal as the collections were supervised by investigators who were familiar to staff and patients as they had worked on the wards for over 2 years in other capacities.

The present investigation was approved by the Joint Ethical Subcommittee of the Southampton and South West Hampshire Health Authority and the Faculty of Medicine of the University of Southampton.

\section{MATERIALS AND METHODS}

Diet collection. Each item of oral intake was exactly reproduced, including hospital meals and snacks, sweets, medicines, and any food brought by visitors. One of the duplicates was presented to the patient for consumption and the other reserved for analysis. Any portions remaining after the patients had finished were collected as 'rejects' for analysis. Care was taken at all stages to avoid contamination. Food was collected into trace-metal-free, acidwashed white plastic containers.

Blood collection. Venous blood was collected with minimum stasis from nineteen patients between 09.00 and 10.00 hours. Separation of leucocytes was undertaken immediately on $15 \mathrm{ml}$ of the blood taken into an acid-washed siliconized glass tube containing heparin. Plasma $\mathrm{Zn}, \mathrm{Cu}$, caeruloplasmin, retinol-binding protein (RBP) and albumin concentrations were determined on blood taken into trace-metal-free tubes containing heparin, and the leucocyte count was estimated on samples taken into trace-metal-free tubes containing EDTA.

\section{Analyses}

Duplicated intakes and rejects for a $5 \mathrm{~d}$ period were homogenized as previously described (Bunker et al. 1984a) and stored at $-20^{\circ}$ before analysis. All samples were analysed in triplicate. Table 1 gives details of all methods used in the present study.

National Bureau of Standards bovine liver was used as reference material and mean values ( $n$ 6) obtained for $\mathrm{Zn}$ were $1.95 \mu \mathrm{mol}$ dry weight (assigned value 1.88 (estimated degree of uncertainty (EDU) 0.12 )) and for $\mathrm{Cu} 2.44 \mu \mathrm{mol} / \mathrm{g}$ dry weight (assigned value 2.49 (EDU 0.11)). Within-batch coefficients of variation for $\mathrm{Zn}$ and $\mathrm{Cu}$ analyses in diet were 3.8 and $4.0 \%$ respectively, and between-batch variation was 4.4 and $4.5 \%$ respectively.

Metabolizable energy (ME) was derived from the formula of Miller \& Payne (1959) converted to SI units:

$$
\mathrm{ME}(\mathrm{kJ})=(\text { gross energy }(\mathrm{kJ}) \times 0.95)-(\text { nitrogen }(\mathrm{mmol}) \times 0.0044) .
$$


Table 1. Details of the methods used in the study

\begin{tabular}{|c|c|c|}
\hline Material & Constituent & Method \\
\hline \multirow[t]{3}{*}{ Food } & Gross energy & Bomb calorimetry* \\
\hline & Protein & $\begin{array}{l}\text { Calculated from nitrogren determined } \\
\text { by semi-automated Kjeldahl } \\
\text { (Tecator, Bristol) }\end{array}$ \\
\hline & Zinc and copper & Dry ashing, FAAS $\dagger$ \\
\hline \multirow[t]{4}{*}{ Plasma } & $\left.\begin{array}{l}\text { Caeruloplasmin } \\
\text { Retinol-binding protein }\end{array}\right\}$ & $\begin{array}{l}\text { Radial immunodiffusion (Hoechst, } \\
\text { UK) }\end{array}$ \\
\hline & $\begin{array}{l}\text { Alkaline phosphatase } \\
(E C \text { 3.1.3.1) }\end{array}$ & $\begin{array}{l}\text { SP } 120 \text { Analyser (Vickers, } \\
\text { Basingstoke) using 4-nitrophenyl } \\
\text { disodium orthophosphate substrate }\end{array}$ \\
\hline & Albumin & $\begin{array}{l}\text { SP } 120 \text { Analyser (Vickers), bromo- } \\
\text { cresol green dye-binding }\end{array}$ \\
\hline & $\mathrm{Zn}$ and $\mathrm{Cu}$ & FAAS $\ddagger$ \\
\hline Leucocyte & $\mathrm{Zn}$ and $\mathrm{Cu}$ & $\begin{array}{l}\text { Dextran sedimentation§, followed by } \\
\text { FAAS }(\mathrm{Zn}) \text { and ETA AAS }(\mathrm{Cu})\end{array}$ \\
\hline
\end{tabular}

Coefficients of variation for within-batch precision of all these analyses were less than $5 \%$.

FAAS, flame atomic absorption spectrometry; ETA AAS, electrothermal atomization atomic absorption spectrophotometry.

* Miller \& Payne (1959).

$\uparrow$ Bunker et al. $(1984 b)$.

$\ddagger$ Meret \& Henkin (1971).

$\S$ Hinks et al. (1982).

Data were assessed for normality of distribution and where positively-skewed, log transformation was undertaken and geometric means and confidence intervals calculated from transformed data. Where transformation was necessary, this is indicated in the Tables. Means, $95 \%$ confidence intervals, correlation coefficients and unpaired $t$ tests, were calculated using the Minitab package (Minitab Inc., 1985) on an IBM 3090/150 mainframe computer. A probability value of $P<0.05$ was accepted as significant.

\section{RESULTS}

The results for the four men did not differ greatly from those for the women and as the former were too small a number to be considered separately, the twenty-one subjects were considered as a whole.

Daily body-weights were stable over a 12 month period in eight patients $( \pm 2 \mathrm{~kg}$ ), but weight losses of $2-4 \mathrm{~kg}$ were observed in ten patients and weight losses of $5-6 \mathrm{~kg}$ in three patients. The meals served to the twenty-one patients offered a daily mean ME content of $6.23 \mathrm{MJ}$, protein content of $57 \mathrm{~g}$, and $\mathrm{Zn}$ and $\mathrm{Cu}$ contents of 110 and $18 \mu \mathrm{mol}$ respectively if completely consumed. Table 2 presents the means and $95 \%$ confidence intervals, for the actual intakes of $\mathrm{ME}$, protein, $\mathrm{Zn}$ and $\mathrm{Cu}$ expressed as amount per day, per $\mathrm{kg}$ body-weight per day, and per $10 \mathrm{MJ}$ energy. Table 3 presents the means and $95 \%$ confidence intervals for the biochemical indices of $\mathrm{Zn}$ and $\mathrm{Cu}$ status. Of the mean total $\mathrm{ME}$ intake $15 \%$ was derived from protein. There was a significant correlation between $\mathrm{ME}$ intake and protein intake $(r 0.63, P=0.003)$. This relation was strengthened by taking account of body-weight $(r 0.89, P<0.001)$. Daily ME intake and body-weight were not related $(r 0.22)$. 
Table 2. Nutrient intake in twenty-one geriatric inpatients by duplicate meal analysis over a 5 d period

\begin{tabular}{|c|c|c|c|c|c|}
\hline Nutrient & Units/d & $\begin{array}{l}\text { Recommended } \\
\text { intake* }\end{array}$ & Mean intake & $\begin{array}{l}95 \% \text { Confidence } \\
\text { interval }\end{array}$ & $\begin{array}{l}\text { Mean intake of } \\
\text { apparently healthy } \\
\text { elderly } \dagger\end{array}$ \\
\hline \multirow[t]{2}{*}{ Energy } & MJ ME & $10(9)$ o & $5 \cdot 16$ & $4 \cdot 66-5 \cdot 66$ & $7 \cdot 58$ \\
\hline & $\mathrm{kJ} / \mathrm{kg}$ body-wt & - & $89 \cdot 7$ & $75 \cdot 7-103 \cdot 6$ & 114 \\
\hline \multirow[t]{2}{*}{ Protein } & $\mathrm{g}$ & $\begin{array}{l}60(54) \stackrel{x}{\circ} \\
47(42) \stackrel{q}{q}\end{array}$ & $44 \cdot 6$ & $39 \cdot 7-49 \cdot 6$ & $64 \cdot 1$ \\
\hline & $\begin{array}{l}\mathrm{g} / \mathrm{kg} \text { body-wt } \\
\mathrm{g} / 10 \mathrm{MJ} \mathrm{ME}\end{array}$ & - & $\begin{array}{l}0.79 \\
87 \cdot 2\end{array}$ & $\begin{array}{l}0 \cdot 66-0 \cdot 92 \\
80 \cdot 3-94 \cdot 1\end{array}$ & $\begin{array}{l}0.97 \\
86.0\end{array}$ \\
\hline Zinc & $\begin{array}{l}\mu \mathrm{mol} \\
\mu \mathrm{mol} / \mathrm{kg} \text { body-wt } \\
\mu \mathrm{mol} / 10 \mathrm{MJ} \mathrm{ME}\end{array}$ & $\begin{array}{r}229 \\
- \\
-\end{array}$ & $\begin{array}{c}85 \cdot 1 \\
1 \cdot 47 \\
167\end{array}$ & $\begin{array}{l}75 \cdot 7-94 \cdot 5 \\
1 \cdot 24-1 \cdot 70 \\
151-182\end{array}$ & $\begin{array}{l}137 \\
2.09 \\
177\end{array}$ \\
\hline Copper & $\begin{array}{l}\mu \mathrm{mol} \\
\mathrm{mmol} / \mathrm{kg} \text { body-wt } \\
\mu \mathrm{mol} / 10 \mathrm{MJ} \mathrm{ME}\end{array}$ & $\begin{array}{c}31 \cdot 5-47 \cdot 2 \\
- \\
-\end{array}$ & $\begin{array}{c}13 \cdot 2 \ddagger(14 \cdot 1) \\
0 \cdot 22 \ddagger(0 \cdot 24) \\
26 \cdot 2 \ddagger(27 \cdot 7)\end{array}$ & $\begin{array}{l}11 \cdot 2-15 \cdot 8 \\
0 \cdot 18-0 \cdot 27 \\
22 \cdot 4-30 \cdot 8\end{array}$ & $\begin{array}{c}18 \cdot 7 \ddagger(20 \cdot 1) \\
0 \cdot 28 \ddagger(0 \cdot 32) \\
24 \cdot 1 \ddagger(26 \cdot 6)\end{array}$ \\
\hline
\end{tabular}

ME, metabolizable energy.

* Department of Health and Social Security (1979 $a$ ) recommended daily intakes of energy and protein, values for 65-74-year-olds, with values for 75-year-olds in parentheses; Food and Nutrition Board (1980) recommended daily dietary allowance for $\mathrm{Zn}$, and estimated safe and adequate dietary intake for $\mathrm{Cu}$ for $51+$ years.

$\dagger$ Energy and protein, Bunker et al. $(1987 b)$; $\mathrm{Zn}$ and $\mathrm{Cu}$, Bunker et al. (1984a).

$\$$ Values are geometric means with arithmetic means in parentheses.

Table 3. Biochemical indices of zinc and copper status in twenty geriatric inpatients

(Mean values and $95 \%$ confidence intervals)

\begin{tabular}{|c|c|c|c|c|}
\hline & \multicolumn{2}{|c|}{ Geriatric inpatients } & \multicolumn{2}{|c|}{$\begin{array}{c}\text { Healthy elderly } \\
\text { controls } \dagger\end{array}$} \\
\hline & Mean & $\begin{array}{c}95 \% \\
\text { Confidence } \\
\text { interval }\end{array}$ & Mean & $\begin{array}{c}95 \% \\
\text { Confidence } \\
\text { interval }\end{array}$ \\
\hline Plasma $\mathrm{Zn}(\mu \mathrm{mol} / \mathrm{l})$ & $10 \cdot 7$ & $10 \cdot 0-11 \cdot 5$ & $11 \cdot 0$ & $10 \cdot 5-11 \cdot 5$ \\
\hline Leucocyte $\mathrm{Zn}$ (pmol $/ 10^{6}$ cells) & 91 & $81-101$ & 120 & $110-130$ \\
\hline Plasma Cu $(\mu \mathrm{mol} / \mathrm{l})$ & $25 \cdot 5$ & $23 \cdot 2-27 \cdot 8$ & $19 \cdot 4$ & $18 \cdot 0-20 \cdot 8$ \\
\hline Leucocyte $\mathrm{Cu}\left(\mathrm{pmol} / 10^{6}\right.$ cells) & $7 \cdot 5$ & $6 \cdot 1-8.9$ & $11 \cdot 5$ & $10 \cdot 0-12 \cdot 9$ \\
\hline \multicolumn{5}{|l|}{ Plasma: } \\
\hline Retinol-binding protein (mg/l) & 39 & 3447 & 46 & $42-50$ \\
\hline Caeruloplasmin (mg/l) & 408 & $361-455$ & 330 & $297-363$ \\
\hline Alkaline phosphatase ( $E C$ 3.1.3.1) (i.u./1) & $244^{*}(263)$ & $200-297$ & 194 & $174-214$ \\
\hline Albumin $(\mathrm{g} / \mathrm{l})$ & 35 & $33-37$ & 45 & $44-46$ \\
\hline
\end{tabular}

* Geometric mean with arithmetic mean in parentheses.

$\dagger$ Bunker et al. (1984a).

There was a close relation between $\mathrm{Zn}$ and protein intakes $(r 0.79, P<0.001)$. Again, the relation was strengthened by allowing for body-weight $(r 0.95, P<0.001)$. Similarly, intakes of $\mathrm{Cu}$ and protein were significantly correlated $(r 0.47, P=0.05)$ and taking account of body-weight slightly strengthened the relation $(r 0.50, P=0.03)$. The correlation 


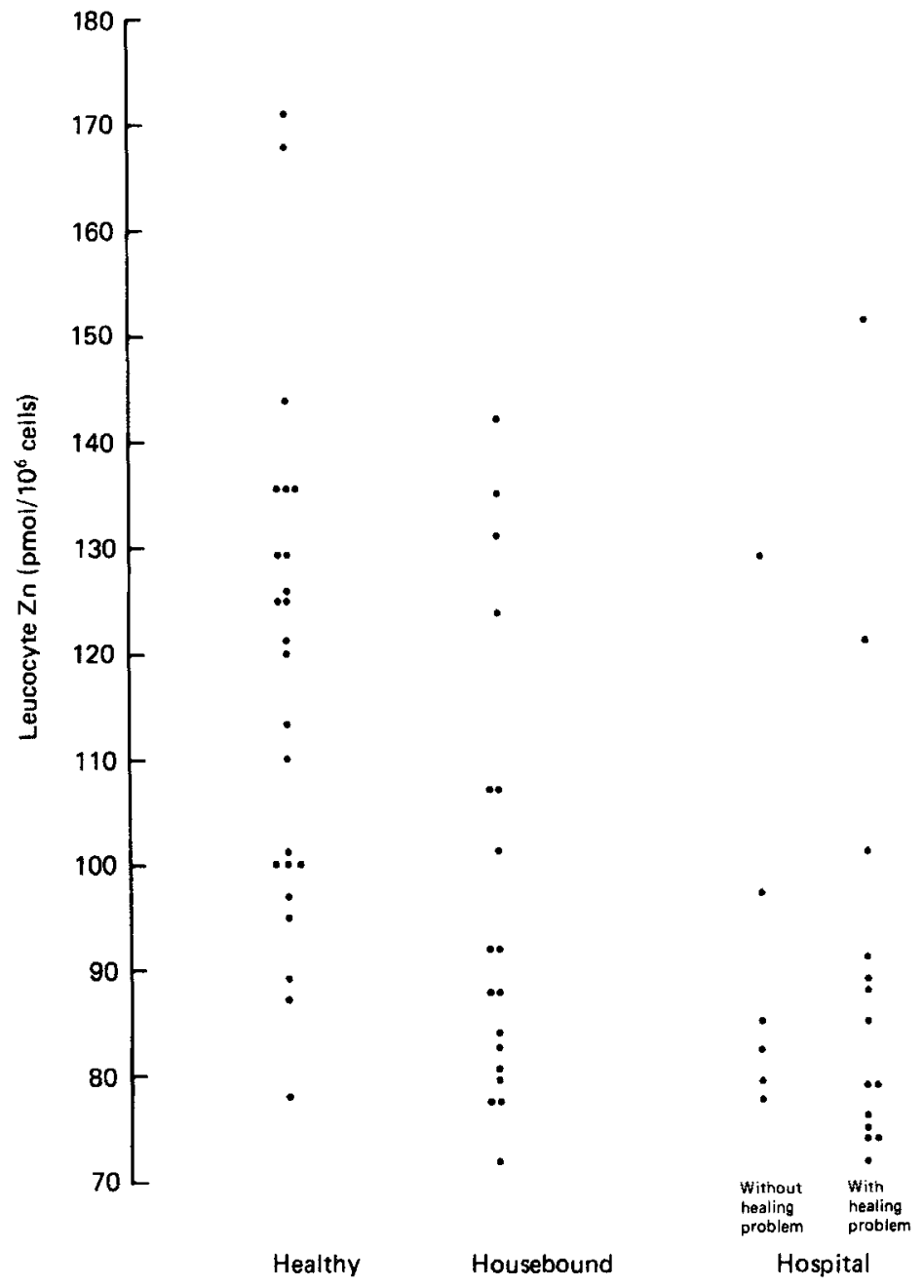

Fig. 1. Leucocyte zinc levels in healthy (Bunker et al. 1984a), housebound (Bunker et al. 1987b) and hospitalized old people (present study).

between $\mathrm{Zn}$ and $\mathrm{Cu}$ intakes was only significant when expressed in terms of body-weight ( $r 0.50, P=0.03$ ).

There was no significant correlation between age and intakes of $\mathrm{ME}$, protein, $\mathrm{Zn}$ or $\mathrm{Cu}$. Neither was any significant relation demonstrated between intakes of $\mathrm{Zn}$ and $\mathrm{Cu}$ and any of the biochemical indices of $\mathrm{Zn}$ and $\mathrm{Cu}$ status measured.

There was no significant difference between patients with or without healing problems in relation to intakes of $\mathrm{ME}$, protein, $\mathrm{Zn}$ and $\mathrm{Cu}$. Neither were there any significant differences between these two groups in terms of plasma $\mathrm{Zn}$, leucocyte $\mathrm{Zn}, \mathrm{RBP}$, plasma albumin, alkaline phosphatase (EC 3.1.3.1), plasma $\mathrm{Cu}$ or caeruloplasmin. However, those patients with healing problems had leucocyte $\mathrm{Zn}$ levels that clustered at the lower end of the range, as illustrated in Fig. 1. Fig. 1 includes results for healthy (Bunker et al. 1984a) and housebound (Bunker et al. 1987 b) elderly subjects for comparison. 


\section{DISCUSSION}

The proper conduct of the duplicate-diet technique and trace-element analysis demand meticulous methodology in collection and preparation of samples, and high analytical standards. Such studies are time-consuming and labour intensive. The number of patients in our study is necessarily small but to the best of our knowledge it is the only study in the UK to date using analysed, rather than calculated, values in this population. Values calculated from food tables can be misleading (Lawson et al. 1982).

We have demonstrated an ME intake of less than two-thirds the recommended level (DHSS, 1979a). Protein intake was marginally lower than that advised, but $\mathrm{Zn}$ and $\mathrm{Cu}$ intakes were only $40 \%$ of the available recommendation (Food and Nutrition Board, 1980). Recently, in a published abstract, low intakes for $\mathrm{Zn}$ and $\mathrm{Cu}$ were recorded in a similar population in Edinburgh but these values were calculated from food tables (Henery \& Smith, 1987).

Recommended allowances are intended as guidelines for an adequate intake and include a safety margin. Informed application of these ideal values is of great importance. Schneider et al. (1986) have drawn attention to the lack of specific recommendations for the elderly and the many factors which will complicate the task, and there are as yet no guidelines regarding trace element intake in this group.

The present results are best compared with metabolic balance information on healthy and housebound elderly people studied in their own homes in Southampton using the same methodology (Bunker et al. $1984 a, 1987 b$ ). The mean daily ME intake of $5.2 \mathrm{MJ}$ in the hospitalized elderly was $30 \%$ lower than that of the healthy elderly $(7.2 \mathrm{MJ})$. We are unable to compare energy expenditure in these two groups. The healthy elderly may be thought to be more physically active on first impressions, but considerable energy may be expended in the achievement of very limited mobility by a disabled person (Isakov et al. 1985).

The mean daily protein intake of $45 \mathrm{~g}$ for the hospital population represents threequarters that of the healthy elderly $(64 \mathrm{~g})$ (Bunker et al. 1987 b). This relatively small difference may be important when tissue repair and muscular development are significant anabolic functions. The percentage of energy derived from protein was identical in both groups $(15 \%)$.

The hospitalized elderly had a mean daily $\mathrm{Zn}$ intake of less than two-thirds that of the healthy elderly ( $85 \mu \mathrm{mol}$ compared with $137 \mu \mathrm{mol}$ ) (Bunker et al. 1984a). The situation was similar for $\mathrm{Cu}$, mean daily intakes being 13 and $20 \mu \mathrm{mol}$ for the hospital and healthy populations respectively.

$\mathrm{ME}$, protein, $\mathrm{Zn}$ and $\mathrm{Cu}$ intakes, whether expressed per day, per $\mathrm{kg}$ body-weight per day, or per $10 \mathrm{MJ}$ are comparable in the housebound (Bunker et al. 1987 a,b) and hospitalized groups. Indeed, the housebound elderly of Bunker et al. $(1987 a, b)$ and the present hospitalized subjects were similar in terms of ill-health and dependency and distinguishable primarily by their differing environments, the disabilities of the former being supported in the community, the latter in hospital. It has been well-recognized since Sheldon's (1948) original observations on the elderly in Wolverhampton that great disability and dependence can be managed at home.

The results of eight reports concerned with the intakes of $\mathrm{ME}$ and protein in elderly subjects in the UK are summarized in Table 4. The low mean ME intake of our subjects is similar to findings in other studies of the elderly at home, in sheltered housing and in hospitals in Britain using dietary recall or weighed inventory. When comparing these values with the recommended daily amounts (DHSS, 1979a) we should bear in mind that studies using calorimetry have suggested that we are overestimating energy requirements (Daly et al. 1985) and that adaptation may occur at low levels of energy intake (Waterlow, 1986). 
Nevertheless, low ME intakes have been linked to high mortality from stroke (Lapidus et al. 1986).

Protein intakes were probably adequate in our study, at a level commensurate with the World Health Organization's recommendation for the elderly of not less than $0.75 \mathrm{~g}$ goodquality protein $/ \mathrm{kg}$ body-weight per $\mathrm{d}$ (World Health Organization, 1985), although overall mean intakes were somewhat lower than others have found (Table 4). Protein synthesis and degradation are linked with both protein intake per se, and non-protein energy intake acting as summative stimulating factors for these processes (Reeds, 1983). However, this linkage is not inextricable and the effects of chronic subnutrition and illness are ill-defined. Indeed, protein utilization may be less efficient in the elderly than in the young (World Health Organization, 1985).

The apparently healthy elderly people studied by Bunker et al. (1984a) were in metabolic balance for $\mathrm{Zn}$ and $\mathrm{Cu}$ and displayed no clinical or biochemical signs of deficiency despite an intake of $\mathrm{Zn}$ and $\mathrm{Cu}$ which was $60 \%$ of that recommended for younger people (Food and Nutrition Board, 1980). Analysed intakes for these essential trace elements in this group of ill elderly people in hospital were well below half the recommended daily amounts (DHSS, 1979a; Food and Nutrition Board, 1980) at a time when good nutrition was of paramount importance. This situation obtains in a Health District where the hospital kitchens have won awards for excellence and every care is taken by the staff to cater for individual preference. The nutrient density offered by the hospital diet was similar to that found for the diet eaten by apparently healthy elderly people in the community (Bunker et al. $1984 a$ ). This suggests a reduced intake of food by patients rather than the provision of an inadequate diet.

In contrast to the healthy elderly, although displaying no clinical evidence of deficiency (and chronic marginal deficiency may present quite differently to an acute severe deficit) the inpatients had low levels of leucocyte $\mathrm{Zn}$. Most of the evidence linking improvement of healing with $\mathrm{Zn}$ supplementation is circumstantial (Pories et al. 1967; Husain, 1969; Haeger \& Lanner, 1974). Many studies on healing and $\mathrm{Zn}$ supplementation failed to make any assessment of $\mathrm{Zn}$ status, and those that did relied on plasma $\mathrm{Zn}$ levels which are affected by many non-specific factors including stress and infection (Delves, 1985). The value of leucocyte $\mathrm{Zn}$ as an index of tissue stores has been well-reviewed elsewhere (Patrick \& Dervish, 1984; Delves, 1985). Our own patients had a lower range of leucocyte Zn levels than the group of healthy elderly (Bunker et al., 1984a) and the leucocyte Zn levels of those with healing problems clustered at the lower end of this range. Leucocyte Cu levels were lower in these elderly inpatients than in the apparently healthy elderly (Bunker et al. 1984a), perhaps suggesting tissue deficit and suboptimal body $\mathrm{Cu}$ status. Low levels of leucocyte $\mathrm{Zn}$ have also been found in another study of long-stay geriatric patients (Stafford et al. 1987).

Values for plasma RBP concentrations were similar in housebound and hospitalized people and lower than those in healthy elderly in Southampton. Plasma albumin levels were lower in the hospital group, but patients were recumbent for venepuncture and this may have affected the value obtained (Freeman \& Cox, 1984). Plasma $\mathrm{Zn}$ levels were comparable in all three groups and leucocyte $\mathrm{Zn}$ showed a downwards trend through the three groups, from healthy to housebound to hospitalized. Plasma $\mathrm{Cu}$ and caeruloplasmin levels were similar in the housebound and hospitalized patients and higher than those in the healthy. This was not unexpected as most $\mathrm{Cu}$ in plasma is bound to caeruloplasmin which is an acute-phase protein.

The low mean intake of $\mathrm{Zn}$ and low concentrations of leucocyte $\mathrm{Zn}$ suggest a state of chronic marginal deficiency. Foods rich in protein are usually rich in $\mathrm{Zn}$ (Osis et al. 1972). Although protein intakes were just adequate in our group, $\mathrm{Zn}$ intakes were suboptimal. 
A. J. THOMAS AND OTHERS

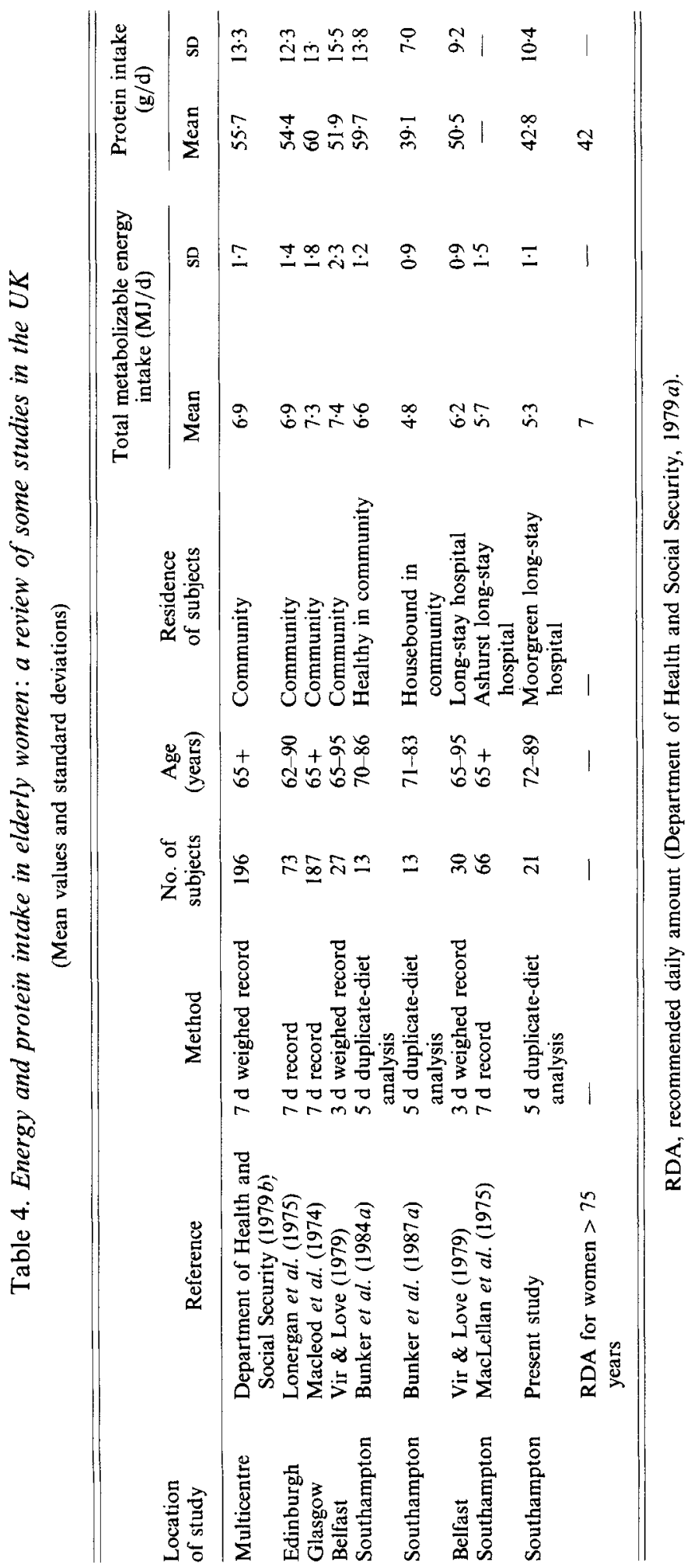


Some hospitals use textured vegetable protein in the form of 'extended mince', but the hospital in which the present study was conducted does not. The foods from which the hospital meals were prepared were fresh or frozen, so losses during processing or preservation were unlikely (Shroeder, 1971).

It is a common observation that old people prefer food that requires little chewing and bland rather than strong flavours. This may explain the apparent incongruity between the $\mathrm{Zn}$ and protein intakes in our patients. Many otherwise excellent studies of nutrition in the elderly fail to assess the state of dentition which is of obvious importance in the selection and ingestion of food. Smith (1977), in her study of the oral health and dental status of 254 elderly people living at home, found that almost one-third had difficulty chewing and more than one in ten had needed to change the type of food eaten, or method of cooking, to enable them to chew effectively. Over three-quarters of our patients were edentulous and half reported problems with dentures that interfered with eating. The nutritional effects of tooth loss have been well-reviewed by Geissler \& Bates (1984). Protein requirements may be met by milk, eggs, cheese and perhaps the white meats that are palatable to the elderly and prepared as dishes that are easy to eat. Coincidentally these foods contain less Zn per g protein than red meat (Murphy et al. 1975). Indeed, roast beef has been removed from the menu in the hospital studied as so much was wasted, although minced ham and lamb are still presented. It may be, therefore, that at a critical level of intake self-selection results in lower-than-adequate daily $\mathrm{Zn}$ intake, but sufficient protein.

The present vogue for adding bran to many dishes, such as porridge, soups and pies (as occurs in this hospital) may be counterproductive as it is well-known that phytate may decrease the amount of $\mathrm{Zn}$ and $\mathrm{Cu}$ available for absorption in the intestinal lumen (Rheinhold et al. 1976; Davies \& Olpin, 1979; Turnlund et al. 1984). Similarly, the higher than recommended daily intake of $\mathrm{Ca}$ and $\mathrm{P}$ in this group, revealed by our own unpublished results, may render more of the dietary $\mathrm{Zn}$ unavailable (Sandstead, 1982). An increase in the level of dietary protein results in increased dietary provision of $\mathrm{Zn}$, by virtue of its intrinsic content and also increased retention of $\mathrm{Zn}$ (Greger \& Snedeker, 1980).

We have studied a small number of elderly people and find that, for $\mathrm{Zn}$ and $\mathrm{Cu}$, institutional malnutrition (Bender, 1984) is a real possibility. Recommendations on the advisability of increasing the ME intakes cannot be made on the information presented here, but these low levels of intake should not be accepted with equanimity merely on the basis of apparent reduction in physical activity, especially with evidence of weight loss in over half the patients studied. Intakes of $\mathrm{Zn}$ and $\mathrm{Cu}$ should be improved commensurate with those found in healthy elderly people in metabolic balance for these elements. Measures that may reduce the availability of trace elements, such as the addition of extra fibre, should not be implemented before careful consideration. Nutritional intake generally could be improved if patients were to eat in small groups, more attention were paid to oral health, and foods were presented so that it could be eaten without utensils if necessary. Strategies that may improve $\mathrm{Zn}$ and $\mathrm{Cu}$ intakes without resort to supplementation include increasing the proportion of $\mathrm{Zn}$-rich protein sources in the diet, as well as increasing the protein density of the diet. If supplementation is considered this should be at physiological rather than pharmacological levels as side-effects of $\mathrm{Zn}$ supplementation have been reported (Moore, 1978).

The authors are very grateful to the patients, nursing staff and catering staff at Moorgreen Hospital for all their help during this study. Professors M. R. P. Halls and R. S. J. Briggs and Dr I. R. Reid kindly gave permission for patients under their care to be studied. The authors would particularly like to thank Professor Hall for his help and interest. The study was supported financially by the BMA Charlotte Eyck Award (held by A. J. T.), the 
Foundation for Age Research, The Wessex Medical School Trust, and Associated Octol Ltd. They are also indebted to Dr M. Campbell of Community Medicine, Medical Statistics and Computing, Faculty of Medicine, University of Southampton for statistical advice.

\section{REFERENCES}

Andrews, K. (1985), British Medical Journal 290, 1023-1024.

Bender, A. E. (1984). British Medical Journal 288, $92-93$.

Bunker, V. W., Hinks, L. J., Lawson, M. S. \& Clayton, B. E. (1984a). American Journal of Clinical Nutrition 40 , 1096-1102.

Bunker, V. W., Hinks, L. J., Stansfield, M. F., Lawson, M. S., Clayton, B. E. (1987a). American Journal of Clinical Nutrition 46, 353-359.

Bunker, V. W., Lawson, M. S., Delves, H. T. \& Clayton, B. E. (1984b). American Journal of Clinical Nutrition 39 , 797-802.

Bunker, V. W., Lawson, M. S.s Stansfield, M. F., Clayton, B. E. (1987b). British Journal of Nutrition 57 , 211-221.

Chandra, R. K. (1980). American Journal of Clinical Nutrition 33, 736-738.

Daly, J. M., Heymsfield, S. B., Head, C. A., Harvey, L. P., Nixon, D. W., Katzeff, H. \& Grossman, G. D. (1985). American Journal of Clinical Nutrition 42, 1170-1174.

Davies, N. T. \& Olpin, S. E. (1979). British Journal of Nutrition 41, 590-603.

Delves, H. T. (1985). Clinical Endocrinology and Metabolism 14, 725-760.

Department of Health and Social Security $(1979$ a). Recommended Daily Amounts of Food Energy and Nutrients for Groups of People in the United Kingdom. Report on Health and Social Subjects no. 15. London: H.M.S.O.

Department of Health and Social Security $(1979 b)$. Nutrition and Health in Old Age. Report on Health Subjects no. 16. London: H.M.S.O.

Department of Health and Social Security (1986). Hospital Inpatient Enquiry 1984. Office of Population Censuses and Surveys Series MB4 no. 24, London: H.M.S.O.

Fenton Lewis, A. (1981). British Medical Journal 283, 1217-1219.

Food and Nutrition Board (1980). Recommended Dietary Allowances, 9 th revised ed. Washington DC: National Academy of Sciences.

Freeman, H. \& Cox, M. C. (1984). In Clinical Biochemistry of the Elderly, pp. 48-74 [H. M. Hodkinson, editor]. Edinburgh: Churchill Livingstone.

Freudenheim, J. L., Johnson, N. E. \& Smith, E. L. (1986). American Journal of Clinical Nutrition 44, $863-876$.

Geissler, C. A. \& Bates, J. F. (1984). American Journal of Clinical Nutrition 39, 478-489.

Greger, J. L. \& Snedeker, S. M. (1980). Journal of Nutrition 110, 2243-2253.

Grundy, E. (1984). British Medical Journal 288, 663-664.

Haeger, K. \& Lanner, E. (1974). VASA Journal for Vascular Diseases 3, 77-81.

Hall, M. R. P. (1974). Medicine 25, 1465-1480.

Henery, E. C. \& Smith, R. G. (1987). Proceedings of the Nutrition Society 46, 63A.

Hinks, L. J., Colmsee, M. \& Delves, H. T. (1982). Analyst 107, 815-823.

Husain, L. (1969). Lancet i, 1069-1071.

Isakov, E., Susak, Z. \& Becker, E. (1985). Scandinavian Journal of Rehabilitation and Medical Suppl. 12 , 108-111.

Lapidus, L., Anderson, H., Bengtsson, C. \& Bosaeus, I. (1986). American Journal of Clinical Nutrition 44, $444-448$.

Lawson, M., Bunker, V., Delves, H. \& Clayton, B. E. (1982). Proceedings of the Nutrition Society 41, 91A.

Lonergan, M. E., Milne, J.S., Maule, M. M. \& Williamson, J. (1975). British Journal of Nutrition 34, $517-527$.

MacLellan, W. J., Martin, P. \& Mason, B. J. (1975). Gerontologica Clinica 17, 173-180.

MacLeod, C. C., Judge, T. G. \& Caird, F. I. (1974). Age and Ageing 3, 158-166.

Meret, S. \& Henkin, R. I. (1971). Clinical Chemistry 17, 369-376.

Miller, D. S. \& Payne, P. R. (1959). British Journal of Nutrition 13, 501-508.

Minitab Inc. (1985). Minitab Reference Manual. Birmingham: CLE. COM.

Moore, R. (1978). British Medical Journal i, 754.

Murphy, E. W., Wells Willis, B. \& Watt, B. (1975). Journal of the American Dietetic Association 66, 345-355.

Osis, D., Kramer, L., Wiatrowski, E. \& Spencer, H. (1972). American Journal of Clinical Nutrition 25, 582-588.

Patrick, J. \& Dervish, C. (1984), CRC Critical Reviews in Clinical Laboratory Sciences 20, 95-114.

Pories, W. J., Henzel, J. H., Rob, C. G. \& Strain, W. H. (1967). Lancet i, 121-124.

Reeds, P. J. (1983). Proceedings of the Nutrition Society 43, 463-471.

Rheinhold, J. G., Faradji, B., Abadi, P. \& Ismail-Beigi, F. (1976). Journal of Nutrition 106, 493-503. 
Sandstead, H. H. (1982). In Clinical, Biochemical and Nutritional Aspects of Trace Elements pp. 83-101 [A. Prasad, editor]. New York: Alan Liss.

Schneider, E. L., Vining, E. M., Hadley, E. C. \& Farnham, S. A. (1986). New England Journal of Medicine 314, 157-160.

Sheldon, J.H. (1948). The Social Medicine of Old Age. London: Nuffield Foundation, Oxford University Press.

Shroeder, H. (1971). American Journal of Clinical Nutrition 24, 562573.

Smith, J. M. (1977). A study of the oral handicaps, dental status and dental needs of an elderly population living at home. Dissertation submitted for Master of Medical Science in Community Medicine, University of Nottingham.

Solomons, N. (1985). Journal of the American College of Nutrition 4, 83-105.

Stafford, W., Smith, R. G., Henery, E. C., Lewis, S. \& O'Rorke, K. (1987). Proceedings of the Nutrition Society 46, $62 \mathrm{~A}$.

Thomas, A. J., Bunker, V. W., Brennan, E. \& Clayton, B. E. (1986). Human Nutrition: Applied Nutrition 40A, $440-446$.

Turnlund, J., King, J., Keyes, W., Gong, B. \& Michel, M. (1984). American Journal of Clinical Nutrition 40, 1071-1077.

Vir, S. C. \& Love, A. M. G. (1979). American Journal of Clinical Nutrition 32, 1934-1947.

Waterlow, J. C. (1986). Annual Review of Nutrition 6, 495-526.

World Health Organization (1985). Energy and Protein Requirements. Technical Report Series no. 724. Geneva: WHO. 